\title{
Institutional Rigidity of the Bretton Woods Institutions, Domestic Politics of the U.S. and the Establishment of the Asian Infrastructure Investment Bank
}

\author{
Dong Kyu Kim, Jaein Lee, Byungwon Woo
}

\begin{abstract}
What explains the establishment of the Asian Infrastructure Investment Bank (AllB) by China? While existing studies have debated Chinese motivations behind the creation of the AlIB being revisionist or status quo oriented, we sidestep the debate and instead try to identify conditions that have provided at least a permissive environment for China to propose and establish the AlIB. We contend that the institutional rigidity, the difficulty with which institutional changes can occur over time, of the BWls played a permissive role in the eventual establishment of the AIIB. We show that China has repeatedly complained its inadequate quota shares since early 2000s, yet its demand for increased quota shares commensurate to its size of economy has met with stiff resistance from status-quo biased countries and with the rigid rules of quota reallocation. The institutional rigidity of the BWIs is further complicated by the salience of the U.S. domestic politics in organizational decision-making of the BWls. We highlight how the US Congress has effectively exerted a veto power over important decisions at the BWIs and how that has inflated Chinese frustration at the BWIs.
\end{abstract}

Key Words: AlIB, IMF, Institutional Rigidity, Bretton Woods Institutions

\footnotetext{
* Dong Kyu Kim(dkckim@yonsei.ac.kr) is currently a research assistant at Korea Institute of Public Administration. He received his Master's degree in Political Science at Yonsei University. His main research interest lies in interaction of international and domestic politics with special focus on international institutions and foreign aid.

* Jaein Lee(leejaein@yonsei.ac.kr) is a Ph. D. candidate in Political Science at Yonsei University. Majoring in international relations and Korean politics, her research focuses on international organizations, regional security, conflict, and cooperation in East Asia.

*Corresponding Author. Byungwon Woo(bwwoo@yonsei.ac.kr) is Associate Professor at the department of political science and international studies at Yonsei University. His research interests include political economy of international institutions, economic statecraft, and human rights. Byungwon Woo's research was supported by the Yonsei University Research Fund of 2019-22-0017.
} 


\section{INTRODUCTION}

The landscape of global economic institutions has undergone a drastic shift in the last decade. Compared to the previous 60 years of relative stability since the end of World War II, when the US-created Bretton Woods Institutions (BWIs) provided institutional stability over global economic governance, the last 10 years has witnessed the emergence of new international economic institutions in countries with rising economic influence. Most notably, a few South American countries led by Brazil, Argentina, and Venezuela signed to establish the Bank of the South in 2009; the leading emerging economies of Brazil, Russia, India, China, and South Africa, collectively dubbed BRICS, signed to found the New Development Bank (NDB) in 2014; and China led the initiative to create the Asian Infrastructure Investment Bank (AIIB) in 2015.

Among the new international economic institutions, the AIIB attracted the most attention, as it is the largest and most global initiative by a new emerging power that most consider capable of rivalling the reigning hegemon, the United States. The AIIB began its operations in 2016 with 57 founding members, and the number of member countries quickly grew to about 100 countries three years after its inception. As of December 2019, more than two dozen countries were waiting to join the AIIB. This is a significant development, because the United States openly opposed the establishment of the AIIB, viewing it as a threat to the US-led global economic order, and actively lobbied its allies not to join the institution (Higgins and Sanger 2019).

Earlier studies on the establishment of the AIIB tried to read China's true intention to create the AIIB. Those who see China as a revisionist power potentially challenging both the United States and the existing international economic order, which the United States has created and maintained, caution that the AIIB is the first step for China in building rival international economic institutions against US-led ones. Those who are in support of the AIIB deny such allegations and emphasize that the AIIB would play a complementary role to existing economic institutions, including the Asian Development Bank (ADB), International Monetary Fund (IMF), and World Bank, to provide much-needed financial resources for regional and global infrastructure projects.

We do not intend to engage in the debate over whether the AIIB is a show of Chinese revisionist intention or not and, hence, sidestep the debate. We instead try to identify underlaying conditions that have provided at least a permissive environment for China to propose and establish the AIIB and how the initiative has garnered wide support from other countries, including key US allies such as the UK, France, Germany, Canada, Australia, and South Korea. What we propose 
thus complement existing studies of Chinese intentions.

We contend that the institutional rigidity-the difficulty with which institutional changes occur over time-of the BWIs played a permissive role in the eventual establishment of the AIIB. Most significantly, rules for rearranging the IMF and International Bank for Reconstruction and Development (IBRD, a main branch of the World Bank) quotas are opaque and open to political influence from larger stakeholders of the BWIs. These rules have not allowed for accommodation of the rising Chinese economy in a timely manner. China has consistently complained about its inadequate quota shares, yet its demand for an increase commensurate with the size of its economy has been met with strong resistance from status quo-biased countries and rigid quota reallocation rules. This rigidity has been repeatedly pointed out by emerging countries but has not been addressed, causing many rapidly emerging economies to become increasingly frustrated with the BWIs.

We also note that US domestic politics provided an additional incentive to consider alternative international institutions. Specifically, the US Congress has been dominated by discourse over the rise of China and its potential threats; consequently, even the agreed upon quota adjustment in 2010 took more than five years to be finally implemented and entered into force. The US Congress held a key de facto veto over the implementation of the quota adjustment agreed to by BWI members, effectively blocking it for over five years. China's frustration with the BWIs grew. Our theoretical approach has several advantages. First, our framework is compatible with either 'revisionist' or 'status quo' position as we identify underlying conditions that generates favorable environment for an alternative. Second, by identifying both domestic and international level factors associated with the establishment of the AIIB, we provide a more general and applicable framework that can be applied to other state or institutional settings.

The paper proceeds as follows. The following section reviews existing studies of China's creation of the AIIB and its possible motivations. In the main section, we discuss how the institutional rigidity of the BWIs and the domestic politics of the United States provided a permissive or encouraging environment for China to create alternative economic institutions, including the AIIB. In the concluding section, we provide policy implications based on our analysis.

\section{LITERATURE REVIEW (CONCERNING AIIB CREATION)}

Given China's dramatic economic growth over the past four decades and its 
current status as the second largest economy in the world next to the United States, the debate regarding the rise of China has recently intensified among International Relations (IR) scholars and policy makers. With China's emerging presence on the global economic landscape, many have made particular reference to the Chinese-led multilateral institution, the AIIB. It was first publicly announced in October 2013 by Chinese President Xi Jinping, who stated that the purpose of the institution was to "promote interconnectivity and economic integration in the region" and "cooperate with existing multilateral development banks" such as the World Bank and ADB (Weiss 2017, 1). The AIIB was formally established on December 25, 2015, with 57 founding members, including four countries (France, Germany, Italy, United Kingdom) of the G-7 group.

The discussion concerning the AIIB largely overlaps with the broader debate over China's role and intent as a rising global power. The existing literature has generally been divided between two perspectives. The first position considers China a 'status quo' power, committed to maintaining the US-built Western liberal economic order (Chow 2016; Gu 2017; Stephen and Skidmore 2019). They emphasize that the AIIB would complement existing institutions by providing additional resources and expertise to the region. On the other hand, some regard China as a 'revisionist' power, eager to create a Chinese-led global order (Hameiri and Jones 2018; He and Feng 2019). To revisionists, China's AIIB creation marks the beginning of the country's ambitious plan to gradually undermine US influence in the region and the existing multilateral economic order. The difference between the two perspectives arises from conflicting interpretations of the roles, intentions, and preferences of China in establishing the AIIB.

The 'status quo' position argues the AIIB would not displace the current BWIs, as the AIIB's purpose and scope are narrow. Rather than diminishing the BWIs' influence, proponents of this position claim that the AIIB would play a complementary role by emphasizing 1) the stated purpose of the AIIB to establish much-needed "infrastructure" and 2) the limited focus of the AIIB on strictly economic functions in Asia and regions immediately beyond it (Chow 2016; Gu 2017). These scholars often cite Article 1 of the AIIB Articles of Agreement, which states the following:

(i) foster sustainable economic development, create wealth and improve infrastructure connectivity in Asia by investing in infrastructure and other productive sectors, and (ii) promote regional cooperation and partnership in addressing development challenges by working in close collaboration with other multilateral and bilateral development institutions (AIIB). 
The phrase "working in close collaboration with other development institutions" clearly indicates that the AIIB would collaborate with other existing international institutions and pursue cooperation, rather than competition, with them.

Proponents of the 'status quo' argument also claim that China would be able to provide expertise and resources to the Asian region through the AIIB that BWIs cannot adequately supply. China, as both the founder and largest stakeholder of AIIB, has experienced dramatic improvement in its living standards, based on infrastructure-driven development over the past four decades (Gu 2017, 144-145). They argue that China's previous development experience provides insights into the importance of infrastructure for other Asian countries as well (Ren 2016, 435-436). From this perspective, China is cast as a benign patron with expertise and resources that simply wishes to pass on its development model to neighboring Asian countries through the AIIB, especially by focusing on investment in infrastructure sectors ( $\mathrm{Gu}$ 2017, 145, 157). Moreover, BWIs have also acknowledged that their inability to understand local conditions because they often lack regional knowledge and expertise is a central problem, which could be remedied by the AIIB, underscoring the complementary role of the AIIB to the BWIs (Liao 2015).

Estimates of infrastructure investment in Asia by the ADB and World Bank also highlight the need for other funding sources as well. The ADB in 2009 published its estimate that Asian countries would need US $\$ 8$ trillion for infrastructure development from 2010 to 2020, with an average overall infrastructure investment of US $\$ 750$ billion per year (ADB and AIIB 2009, 167-169). The World Bank also found that developing countries in the world would need US $\$ 819$ billion annual investment to establish sustainable infrastructure (Ruiz-Nunez and Wei 2015, 9-10). Estimates for adequate infrastructure development in just South Asia (US\$ 304 billion), East Asia and the Pacific countries (US\$ 212 billion) would amount to US $\$ 516$ billion, accounting for $63 \%$ of the total needed for the world (Ruiz-Nunez and Wei 2015, 13). However, the World Bank's resources for the Asia-Pacific are limited to a mere US $\$ 252$ billion (Chow 2016, 1273-1274). ADB President Takehiko Nakao commented that the creation of the AIIB is "understandable," as there is a large financing need in the region (Ren 2016, 436). Based on this viewpoint, the creation of the AIIB can be interpreted as the reaching of equilibrium between the demand for infrastructure and the supply of resources.

Lastly, scholars who emphasize the complementary quality of the AIIB point to AIIB operational principles that require infrastructure projects to meet the standards set by existing international institutions dominated by Western 
countries (Wang 2015). For example, the AIIB states its core values as "lean, clean, and green," directly adopting sustainable policies promoted by other international organizations such as the United Nations and World Bank. Wang also argues that China, which has reaped economic and political benefits by actively participating in the liberal economic order managed by the BWIs, is not ready to compete with them, and Chinese interests lie in gradual convergence toward the existing system (Wang 2015, 3). Rather than competing against the BWIs and the $\mathrm{ADB}$, China intends to adhere to fundamental banking principles, wherein the core standard is economic, rather than political (Liao 2015).

On the other hand, those who hold a more cautionary view on the AIIB tend to emphasize China's revisionist intentions; they regard the establishment of the AIIB as a reflection of the Chinese challenge to the BWIs and the liberal economic order they represent. These organizations, created and maintained by the United States, are perceived to be acting only on behalf of that country and other Western powers (Hameiri and Jones 2018, 573). Scholars point out, as an instance of political use of the BWIs, the "conditions" attached to BWI loans to developing countries, and these conditions are closely connected to US policy goals "promoting Western-style capitalism" around the world, especially to developing recipient countries (Chow 2016, 1277).

Those who view the AIIB as a Chinese alternative to the BWIs highlight the fact that China has tried to promote the so-called "Beijing Consensus," a Chinese alternative to the Washington Consensus, which emphasizes active government intervention in the process of economic development with a doctrine of non-intervention (Chow 2016, 1279). Such policy direction has raised concerns for some observers of China and how it could attempt to undermine the legitimacy of BWIs by taking away the developing states that have often relied on the World Bank and IMF in the past. This suspicion is also bolstered by President Xi's active pursuit of an ambitious foreign policy agenda by deepening economic, security, and political ties with neighboring countries (Weiss 2017, 2). Moreover, the initial response from the United States, which strongly urged its allies to boycott the AIIB prior to its launch, also reveals how that country has interpreted China's establishment of the AIIB as a means to undermine the BWIs and US influence (Hameiri and Jones 2018, 574; Chow 2016, 1255).

The norms embodied by the AIIB have also been called into question by those who cast China as a revisionist. They argue that the AIIB is attempting to replace existing values such as environmental protection, sustainability, and workers' rights (Chow 2016, 1259). Even before the AIIB's official launch, China promised there would be less "red tape" and fewer or no conditions when it issues loans to recipients (Gu 2017, 146). Such promises of lax conditionalities may be more 
appealing to developing countries sensitive to the issue of liberal democratic norms and could provide incentives for them to abandon the use of existing institutions (Chow 2016, 1280-1285). Gallagher et al. also criticize China, stating that it has financed and built large-scale infrastructure projects, allegedly with little regard for social or environmental standards (Gallagher et al. 2016, 10-11). With respect to such concerns, China has stuck to its position on not infringing on national sovereignty and refused to raise issues about recipient countries' decisions, declaring that states should conduct their internal affairs as they wish (Chow 2016, 1281-1283).

China's non-interventionist stance presents a stark contrast to the BWIs' practice of conditionality. Conditionality-the practice by which loans are provided to governments in return for compliance with specific policy conditions-is the focus of many IMF debates, protests, and even riots (Vreeland 2007, 11). The United States and Western countries have justified attaching conditionalities to loans as a means to safeguard acceptable standards of governance and liberal norms. However, China has regarded conditionalities as infringements on national sovereignty and has often criticized other governments' censuring of China's human and labor rights violations (Chow 2016, 1279). Therefore, critiques have speculated that Chinese assistance through the AIIB would undermine efforts by the United States and BWIs to promote good governance and democracy in developing countries (Weiss 2017, 4).

In sum, most studies of the AIIB's creation have focused on whether it reflects a benign intention on the part of China to build regional infrastructure and cooperate with existing institutions, or an initiation of the building up of a Chinese-led economic order. However, both the status quo and revisionist arguments are focused on individual interpretations of the phenomenon and tend to focus on evidence of a particular AIIB feature that supports their own argument. Therefore, rather than adding another interpretation of the intentions behind China's creation of the AIIB, this paper seeks to address the conditions that led China to create it, arguing that the BWIs' current design and management enabled it.

Our argument is compatible with either side of the existing studies, as we identify the underlying conditions of China's initiation of the AIIB, irrespective of its status quo or revisionist intentions. We extend and fully develop the idea of status deficit that the gap between the actual economic weight of China and Chinese status in managing global political economy and at the Bretton Woods Institutions (Chen 2019). We extend the idea that Chinese efforts to establish the AIIB are driven by China's frustration with the reform failure of the BWIs (Wu 2018, 569), and dig deeper to develop the argument that institutional rigidity of 
the BWIs and US domestic politics are chief culprits of China's frustration. In the next section, we elaborate on how the two factors we identify motivated China to seek an alternative to BWIs and to set up the AIIB.

\section{THE ARGUMENT: INSTITUTIONAL RIGIDITY AND US DOMESTIC POLITICS}

We sidestep the debate over whether the AIIB 1) is a complementary institution with purposes closely aligned to the BWIs (making China a status quo power) 2) or the first realization of Chinese revisionist intentions aimed at the eventual overturn of the current international economic order. We avoid engaging in this debate because it is mainly speculative. It is hard to read the true intentions of China, and there is valid evidence to support both sides of the story.

We instead focus on the existing political and institutional environments that motivated China to create the AIIB and other institutions. Specifically, we identify institutional rigidity, a key institutional characteristic of the BWIs, and the domestic political circumstances of the United States as the two main factors motivating the Chinese creation of the AIIB. The factors we identify are compatible with both sides of the debate and explain the deeper reasons for the AIIB's creation. From a revisionist perspective, the institutional rigidity of the BWIs and the domestic political environment of the United States provided a pretext for China to create alternative institutions with the intent to challenge the existing international economic order led by the United States. From the status quo perspective, the institutional rigidity and domestic political environment prevented China from contributing financially to the BWIs, causing China to decide to create complementary institutions to meet developmental needs, especially in infrastructure investment, in Asia and beyond.

\section{INSTITUTIONAL RIGIDITY OF THE BRETTON WOODS INSTITUTIONS}

China's representation at the IMF and IBRD, the main arm of the World Bank, is broadly comparable. While the World Bank has traditionally been in charge of development finance and is, therefore, more comparable to the AIIB, the IMF's creation of poverty reduction-related, longer-term development-oriented lending programs, and active collaboration between the two BWIs blur the distinctions between the roles of the IMF and the World Bank.

Given China's similar representation at the two BWIs and the murky distinction between the IMF and World Bank, our theoretical discussion in this section 
focuses on the IMF. We do so for three reasons. First, the IMF is the institution with which China has shown the most frustration, over the last 10 years, in particular. This may be because China remains a borrower of the World Bank and may, therefore, be less willing to make complaints to that institution. By contrast, China is freer at the IMF to express its frustration with the institution, as it has not borrowed from the IMF since 1986. Second, the IMF is the more politically controversial institution, and there is particularly loud criticism that the United States is using the institution for its own strategic benefit (Thacker 1999). Third, there are more existing studies of IMF governance than that of the World Bank; therefore, it is more convenient and meaningful to contextualize and engage existing studies by focusing on the IMF.

The most important characteristic of an institution is the representation of each member. Some institutions such as the United Nations General Assembly have an egalitarian system whereby each member reserves equal votes. Other institutions adopt different systems of representation, with most economic institutions having a quota system in which a member's political representation is largely proportional to its financial contribution, often denoted as a quota or as the country's subscription shares as a percentage of its total subscription.

The subscription shares or quota are important because they determine a member's political power within the institution. Formal political power within an institution is based on voting power, and there is a detailed formula to translate subscription shares to voting power. Moreover, subscription shares also determine who among peers will represent and assume the role of executive director of a constituency, a grouping of countries usually within a specific region without a large enough quota to merit its own executive director. Because subscription shares are such an important facet of IMF governance, redistribution of shares is an extremely contentious issue, with most countries wishing to increase or, at least, maintain their own shares (Kaya 2015, 9).

We identify that the institutional rigidity of the BWIs, and especially that of the IMF, in redistributing shares was key to motivating China to create the AIIB. The term 'institutional rigidity' or 'institutional resilience' is often used by new institutionalist scholars who share a common concern for the ways in which institutions, in both domestic and international contexts, shape political activities. Three camps within the new institutionalism schools seek to address the role institutions play in determining political and social outcomes: historical, rational choice, and sociological institutionalism (Hall and Taylor 1996). Although the three schools have different approaches, they do agree on the proposition that institutions are rigid, meaning that the rules, procedures, structures, and norms embodied in the institutions often remain static and do 
not adequately reflect the dynamic changes that may be happening within the institution (Steinmo 2001, 570-574). Despite changing environments and actors, institutional changes rarely occur, and when they do, they often do so in a gradual and incremental manner (Hall and Taylor 1996; Steinmo 2001; North 1990; March and Olsen 1984; Krasner 1984). While the reasons institutions become rigid and unable to adapt to demands for change are not the scope of this paper, previous studies have cited various factors such as elites' preferences, effects of solid interests of veto players, ambiguous jurisdictions, or disagreements over how change might be achieved (Thelen 2009; Lustick 2011; Fioretos 2011).

There have been theoretical efforts to bring these institutionalist perspectives into the study of international relations as well (Voeten 2019; Fioretos 2011, Lipscy 2015). The institutional rigidity has been investigated in the international context, but the conceptualization is not unified amongst the scholars. For example, Koremenos (2005) argues that institutional designs of international cooperation depend on uncertainty, states' risk-aversion behavior, and renegotiation costs. The institutional rigidity, according to Koremenos, is measured by the duration of the provisions agreed by the stakeholders, and the shorter the duration, the more flexible institution becomes. On the other hand, Rosendorff (2005), using WTO's Dispute Settlement Mechanism as a model, argues that there is a trade-off between institutional rigidity and institutional stability. The rigidity here is derived from the legalization and interpretation of the agreement, and more rigid institutions could lower the prospect of further cooperation amongst the states. Johns $(2014,470)$ highlights the compliance aspect of the international agreement by defining rigidity as "the degree to which treaty violations are tolerated."

Given the multifaceted aspects of institutional rigidity (or flexibility), we define institutional rigidity in the broadest sense - the difficulty with which institutional changes occur over time. This lack of change can arise due to multiple factors such as nested interest of veto players, rigid rules and procedures governing changes, or issue areas at stake. In case of BWIs' rigidity, it is associated with all the aforementioned factors which is well reflected in the IMF's history of quota reform.

The IMF was conceived in 1944 as part of the Bretton Woods Agreement to stabilize the international financial system and ultimately support world trade and economic growth (Wyplosz 1999). At its founding, the IMF was originally planned as an institution with two primary mandates: to oversee exchange rates between countries and to provide short-term capital to countries facing balance-of-payments (BoP) difficulties (Jensen 2004). The first function was specifically assigned to the IMF to prevent the competitive and self-destructive 
economic policies of countries prior to World War II, whereby countries competitively devalued their currencies and raised trade barriers to protect their economies. These practices were ultimately self-destructive, as the global trade plummeted sharply, along with employment and economic growth. To safeguard exchange rate stability, the IMF was given the authority to monitor member countries' monetary policies.

The second function of the IMF was to provide temporary financial assistance to countries facing a BoP crisis. The $\mathrm{BoP}$ is an accounting record of international transactions between a country and the rest of the world. If the country's total exports are consistently far lower than its total imports, the country is said to incur a current account deficit. To balance the loss, the government can sell its foreign currency reserves or issue bonds to bring in private capital inflow. If, however, private capital inflow or the selling of foreign reserves does not adequately cover the trade imbalances, the value of the country's currency rapidly declines, distorting the international currency exchange market. As it was created to safeguard currency exchange stability around the globe, the IMF was tasked with providing short-term capital to deficit countries when they exhausted their foreign currency reserves. This assistance would provide the necessary time and resources for countries undergoing crisis to continue necessary imports, adjust economic policies, and stabilize their currencies.

Financing of IMF loans is made from members' subscriptions known as quotas, which are pooled funds from member countries that generate most of the IMF's financial resources. Quotas are initially assigned to members upon entry, based on a specific formula representing members' relative size of economy and characteristics. The current quota formula, established in 2008, is as follows, although it should also be noted that even when there exist formulae and general guidelines in the allocation of quotas, they tend to be politically manipulated by powerful countries leading the institution: ${ }^{1}$

$$
\begin{gathered}
\text { Quotai }=\left(0.50^{\star} G D P_{i}+0.30^{\star} \text { Openness }_{i}+0.15^{\star} \text { Variability }_{i}+\right. \\
\left.0.05^{\star} \text { Reserves }_{i}\right)^{\text {Compression Facto }^{-}}
\end{gathered}
$$

Quota is important for each member because the quota share determines not only members' financial contributions to the Fund but also access rights to IMF financing, Special Drawing Rights (SDR) allocations, and voting rights. Voting

\footnotetext{
${ }^{1}$ See "International Monetary Fund. 2019. "IMF Quotas." International Monetary Fund (March 8). Accessed at https://www.imf.org/en/About/Factsheets/Sheets/2016/07/14/12/21/IMF-Quotas (searched date: December 5, 2019)," for a more detailed quota calculation procedure.
} 
rights are largely determined by a member's quota, which is calculated by equal amounts of basic votes among all members plus one additional vote per SDR 100,000 of quota. This system inevitably leads to uneven distribution and representation among members; as of October 2019, for example, the United States had 831,407 votes, or $16.52 \%$ of total IMF votes, while Tuvalu held only 1,490 votes, constituting $0.03 \%$ of the whole.

As seen in the formula, quotas are measured by four major economic indicators, and GDP is the largest determinant. Although the formula has changed several times during the Fund's existence, the central weight of the formula has always been the member's GDP, as it is the most widely used measure of country's economic capability (Bénassy-Quéré and Béreau 2011). It is also consistent with the functions of quotas: a country with a large GDP would have a higher ability to contribute to the Fund, greater need in the case of a crisis, and higher legitimacy to weigh in on IMF decisions. China has experienced rapid economic growth, with an average 9\% annual economic growth rate for the last two decades. If the formula was faithfully observed, the rapid economic enlargement of China should have been reflected in a proportionally increased Chinese quota. However, the IMF has been unable to adapt to the economic growth of its members, as any changes to quotas are deemed to be strategic issues by its members, and powerful countries such as the United States have the option to block changes.

Quota share restructuring is rare in IMF history. The procedure for increasing quotas begins at the IMF when the Board of Governors conducts a "General Review of Quotas." General reviews are usually held about every five years, and during the review, two issues are mainly discussed: establishing an equal, proportional increase for all members and specific distribution among the members. Any changes must be approved by an $85 \%$ majority of the total voting power, and a member's quota cannot be changed without its consent. The United States has maintained $16 \%$ or higher voting power within the IMF, which allows that country to exercise a de facto veto if deemed necessary. 
Table 1. IMF General Quota Review

\begin{tabular}{|c|c|c|c|c|c|c|c|c|c|}
\hline \multirow[b]{2}{*}{ Quota Review } & \multirow{2}{*}{$\begin{array}{l}\text { Resolution } \\
\text { Adopted }\end{array}$} & \multirow{2}{*}{$\begin{array}{l}\text { Quota } \\
\text { Increase }\end{array}$} & \multirow{2}{*}{$\begin{array}{l}\text { Entry into } \\
\text { Effect }\end{array}$} & \multicolumn{3}{|c|}{ United States } & \multicolumn{3}{|c|}{ China } \\
\hline & & & & $\begin{array}{l}\text { Quota } \\
\text { (\%) }\end{array}$ & $\begin{array}{c}\text { Votes } \\
\text { (\%) }\end{array}$ & $\begin{array}{l}\text { GDP } \\
(\%)\end{array}$ & $\begin{array}{l}\text { Quota } \\
\text { (\%) }\end{array}$ & $\begin{array}{c}\text { Votes } \\
(\%)\end{array}$ & $\begin{array}{l}\text { GDP } \\
(\%)\end{array}$ \\
\hline $\begin{array}{l}\text { Founding } \\
\text { Subscription }\end{array}$ & - & 100.0 & 1948 & 32.5 & 30.64 & 32.19 & - & - & \\
\hline $\begin{array}{l}\text { First } \\
\text { Quinquennial } \\
\text { (1950) }\end{array}$ & $\begin{array}{l}\text { No increase } \\
\text { proposed }\end{array}$ & - & - & 32.0 & 30.62 & 27.28 & - & - & \\
\hline $\begin{array}{l}\text { Second } \\
\text { Quinquennial } \\
\text { (1955) }\end{array}$ & $\begin{array}{l}\text { No increase } \\
\text { proposed }\end{array}$ & - & - & 29.6 & 27.40 & 26.46 & - & - & \\
\hline $1958-59$ & $\begin{array}{l}\text { February, April } \\
1959\end{array}$ & 60.7 & April 1959 & 28.4 & 25.39 & 24.92 & - & - & \\
\hline $\begin{array}{l}\text { Third } \\
\text { Quinquennial } \\
\text { (1960) }\end{array}$ & $\begin{array}{l}\text { No increase } \\
\text { proposed }\end{array}$ & - & - & 27.0 & 25.98 & 27.96 & - & - & \\
\hline $\begin{array}{l}\text { Fourth } \\
\text { Quinquennial }\end{array}$ & March 1965 & 30.7 & $\begin{array}{c}\text { February } \\
1966\end{array}$ & 24.3 & 23.82 & 27.33 & - & - & \\
\hline Fifth General & February 1970 & 35.4 & $\begin{array}{c}\text { October } \\
1970\end{array}$ & 23.1 & 22.03 & 24.98 & - & - & \\
\hline Sixth General & March 1976 & 33.6 & April 1978 & 22.5 & 20.00 & 23.57 & - & - & \\
\hline $\begin{array}{l}\text { Seventh } \\
\text { General }\end{array}$ & $\begin{array}{l}\text { December } \\
1978\end{array}$ & 50.9 & $\begin{array}{c}\text { November } \\
1980\end{array}$ & 21.2 & 20.01 & 24.09 & 3.02 & 2.89 & 1.11 \\
\hline Eighth General & March 1983 & 47.5 & $\begin{array}{c}\text { November } \\
1983\end{array}$ & 20.23 & 19.32 & 23.47 & 2.67 & 2.60 & 1.48 \\
\hline Ninth General & June 1990 & 50.0 & $\begin{array}{c}\text { November } \\
1992\end{array}$ & 18.76 & 17.82 & 23.84 & 2.39 & 2.29 & 2.19 \\
\hline $\begin{array}{l}\text { Tenth General } \\
\text { (1995) }\end{array}$ & $\begin{array}{l}\text { No increase } \\
\text { proposed }\end{array}$ & - & - & 18.25 & 17.83 & 24.35 & 2.32 & 2.29 & 3.50 \\
\hline $\begin{array}{l}\text { Eleventh } \\
\text { General }\end{array}$ & January 1998 & 45.0 & $\begin{array}{c}\text { January } \\
1999\end{array}$ & 17.67 & 17.53 & 25.09 & 2.22 & 2.22 & 4.12 \\
\hline $\begin{array}{l}\text { Twelfth } \\
\text { General (2003) }\end{array}$ & $\begin{array}{l}\text { No increase } \\
\text { proposed }\end{array}$ & - & - & 17.46 & 17.14 & 25.00 & 2.99 & 2.95 & 5.42 \\
\hline $\begin{array}{l}\text { Thirteenth } \\
\text { General }\end{array}$ & $\begin{array}{l}\text { No increase } \\
\text { proposed }\end{array}$ & - & - & 17.09 & 16.77 & 23.80 & 3.72 & 3.66 & 7.27 \\
\hline $\begin{array}{l}\text { Fourteenth } \\
\text { General }\end{array}$ & $\begin{array}{l}\text { December } \\
2010\end{array}$ & 100.0 & $\begin{array}{l}\text { January } \\
2016\end{array}$ & 17.46 & 16.66 & 22.70 & 6.41 & 6.14 & 9.24 \\
\hline Current Quota & $\begin{array}{l}\text { November } \\
2019\end{array}$ & & & 17.46 & 16.52 & 21.62 & 6.41 & 6.09 & 12.66 \\
\hline
\end{tabular}

Source: IMF, World Bank

Table 1 summarizes the evolution of the quota and vote share of China and the United States within the IMF and their share of GDP in the world. There have been nine major quota increases since 1948, with the most recent reform being in 2016. 
Notice that there are often temporal gaps between the date the reform was adopted within the IMF and the actual date that it came into effect. The 14th General Review, for example, was passed by the Board of Governors in 2010 but took more than five years to be implemented. This lag, which will be expounded upon in a later section, can often be explained by the difficulty in obtaining authorization from Congress for an increase in the US quota. With the rules of the IMF reform setting an 85\% supermajority, the United States, which has always held more than $16 \%$ of total votes, has acted as the sole veto player of organizational reform (Broz and Hawes 2006). As any change in quota cannot be made without US approval, the institution has remained rigid with respect to any policies that could diminish US influence on the organization.

Figure 1. US and China GDP/Quota Share (\%)

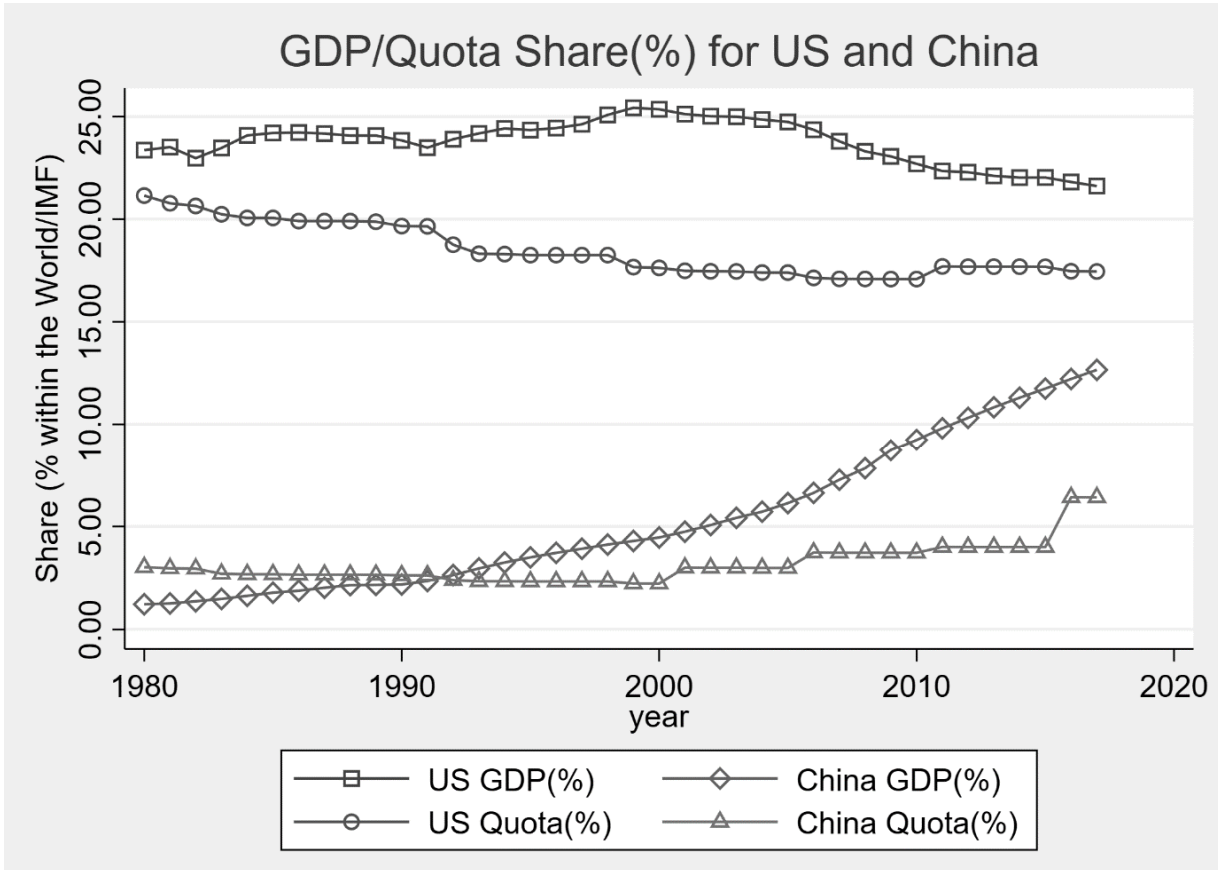

The rigidity of the IMF is more clearly demonstrated in Figure 1, which shows the overall GDP and quota share of the United States and China since 1980. For the United States, GDP share with respect to world GDP and quota share within the IMF are more or less parallel, with a downward slope. On the other hand, for 
China, except for the initial 10 years of entry, the quota share remained nearly flat for almost two decades, while the GDP share grew rapidly. It was not until 2016 when the 2010 IMF quota reform came into effect that the Chinese quota nearly doubled. At its largest discrepancy point, the Chinese share of the world economy was over $10 \%$, yet its quota at the IMF was around $3.7 \%$. Even with implementation of the most recent reform, China's quota is $6.41 \%$, less than half of its GDP share of $12.66 \%$ in 2019.

The under-representation (and over-representation) of certain members have become a major area of contention with the emergence of China and other emerging economies in the global economic landscape. Adding to their frustration was the fact that even the formula has not been faithfully observed. In the IMF Staff Report written in 2015, the staff presented updated calculated quota shares based on the 2008 formula. The report concludes that China's quota share to be raised to at least 10.5 percent while that of US to be lowered to 14.5 percent (IMF 2015). Even with the other components of the formula considered, the report remarks that the share of emerging markets and developing countries (EMDCs) have been under-represented in the IMF quota scheme.

China has openly expressed its frustration and disappointment over failed IMF quota reform, which reflects the organization's inability to adapt to the changing economic power and influence of its members and properly reflect China's status in the world. Table 2 lists a sample of statements made by high-ranking officials of China on IMF quota reform.

Table 2. Statements by Chinese Officials on IMF Quota Reform

\begin{tabular}{|c|c|c|c|}
\hline Date & Person & Position & Description \\
\hline 2009/06/19 & Hu Jintao & President & $\begin{array}{l}\text { Advocates for IMF quota reform that allows emerging } \\
\text { and developing economies a greater say }\end{array}$ \\
\hline 2009/10/06 & Xie Xuren & Finance Minister & $\begin{array}{l}\text { Calls for IMF to speed up quota reform and implement } \\
\text { an automatic adjustment mechanism at the annual IMF } \\
\text { Meeting in Istanbul, Turkey }\end{array}$ \\
\hline $2010 / 04 / 25$ & $\begin{array}{l}\text { Zhou } \\
\text { Xiaochuan }\end{array}$ & Governor of PBC & $\begin{array}{l}\text { Suggests that IMF transfer } 6 \% \text { of quota to the } \\
\text { emerging market and developing economies at the } \\
\text { World Bank Meeting }\end{array}$ \\
\hline $2010 / 10 / 24$ & $\begin{array}{l}\text { Zhou } \\
\text { Xiaochuan }\end{array}$ & Governor of PBC & $\begin{array}{l}\text { Remarks that China supports the G20's decision on } \\
\text { IMF quota reform at the G20 Gyeongju Finance } \\
\text { Ministers' meeting }\end{array}$ \\
\hline $2012 / 06 / 12$ & Zhu Jun & $\begin{array}{l}\text { Deputy Director of } \\
\text { PBC }\end{array}$ & $\begin{array}{l}\text { Urges the IMF to complete the membership quota } \\
\text { reform agreed to in } 2010\end{array}$ \\
\hline $2012 / 06 / 18$ & Hu Jintao & President & $\begin{array}{l}\text { Urges all G20 members to continue to advance reform } \\
\text { of the international financial system and speedily meet } \\
\text { IMF quota and governance reform targets }\end{array}$ \\
\hline $2013 / 04 / 21$ & $\begin{array}{l}\text { Zhou } \\
\text { Xiaochuan }\end{array}$ & Governor of PBC & $\begin{array}{l}\text { Remarks that it is imperative to not further delay the } \\
2010 \text { IMF quota and governance reform }\end{array}$ \\
\hline
\end{tabular}




\begin{tabular}{|c|c|c|c|}
\hline Date & Person & Position & Description \\
\hline $2014 / 04 / 11$ & Yi Gang & $\begin{array}{l}\text { Deputy Governor of } \\
\text { PBC }\end{array}$ & $\begin{array}{l}\text { Warns that the failure to act on the much delayed IMF } \\
\text { quota and governance reform will seriously damage } \\
\text { G20 leadership }\end{array}$ \\
\hline 2014/07/16 & Xi Jinping & President & $\begin{array}{l}\text { Stresses that developing nations should have larger } \\
\text { representation in world affairs and that China will } \\
\text { propose more solutions }\end{array}$ \\
\hline $2014 / 12 / 12$ & Hong Lei & $\begin{array}{l}\text { Foreign Affairs } \\
\text { Ministry Spokesman }\end{array}$ & $\begin{array}{l}\text { Remarks that China is "deeply disappointed" in the } \\
\text { United States' repeated failure to approve the IMF } \\
\text { reform plan }\end{array}$ \\
\hline $2015 / 02 / 02$ & Wang Yi & $\begin{array}{l}\text { Minister of Foreign } \\
\text { Affairs }\end{array}$ & $\begin{array}{l}\text { Calls for immediate reform of the international financial } \\
\text { system to increase the voice and representation of } \\
\text { emerging markets and developing countries in a joint } \\
\text { communiqué of the Russian, Indian, and Chinese } \\
\text { Foreign Ministers' meeting }\end{array}$ \\
\hline 2015/04/18 & $\begin{array}{l}\text { Zhou } \\
\text { Xiaochuan }\end{array}$ & Governor of PBC & $\begin{array}{l}\text { Remarks that IMF members are frustrated with the } \\
\text { delay of the } 2010 \text { IMF quota reform }\end{array}$ \\
\hline 2015/12/19 & $\begin{array}{l}\text { Zhou } \\
\text { Xiaochuan }\end{array}$ & Governor of PBC & $\begin{array}{l}\text { Remarks that China welcomes the ratification of the } \\
2010 \text { IMF reform and that implementation would help } \\
\text { maintain the IMF's legitimacy and credibility }\end{array}$ \\
\hline 2019/04/14 & Chen Yulu & $\begin{array}{l}\text { Deputy Governor of } \\
\text { PBC }\end{array}$ & $\begin{array}{l}\text { Urges the IMF to implement new reform to narrow the } \\
\text { gap between the actual and calculated quotas in a } \\
\text { constructive manner }\end{array}$ \\
\hline $2019 / 10 / 20$ & Yi Gang & Governor of PBC & $\begin{array}{l}\text { Remarks that China is once again deeply disappointed } \\
\text { in the latest IMF quota review, which failed to agree on } \\
\text { a quota increase and quota share realignment }\end{array}$ \\
\hline
\end{tabular}

Source: Xinhua News Agency, Global Times

Ever since the establishment of a formal relationship between China and the IMF in 1980, China has been attempting to expand its influence over the Fund. Influence within the Fund incorporates both formal and informal powers that govern everything from day-to-day management to major bail-out decision-making, and it is the combination of both that makes the United States an unequaled IMF actor (Stone 2011). With its growing international economy and finance presence, China began to demand more representation within the organization, and the IMF has accommodated these requests by adjusting China's quota share and increasing Chinese employees within the organization (Heep 2014, 126-127). However, these adjustments, especially that of quota revision, were rarely satisfactory to China, as they failed to adequately represent China's status in the rapidly changing global economy.

China's attitude toward the IMF for the past decade has been characterized by a cycle of initial hope, followed by frustration and disappointment. In 2009, Chinese President Hu Jintao and Russian President Dmitry Medvedev issued a joint statement during the BRICS Summit, calling for both the World Bank and the IMF to give a larger say and broader representation to emerging markets and 
developing countries (Xinhua News Agency 2009). The Global Financial Crisis that originated in the United States in 2008, along with China's growing presence in the global economy, further legitimized China's concerns. As both the IMF and World Bank were scheduled to conduct their periodic reviews of quota and capital subscription in 2010, the Chinese government, with the support of other BRICS and developing countries, mobilized support to implement the long overdue BWI reform.

The year 2010 seemed promising to China; both the G20 Finance Ministers' meeting in Gyeongju and the G20 Summit in Seoul affirmed that more than 6\% of quota would be transferred to BRICS and other emerging economies (The G20 Research Group 2010). After the G20 Seoul Summit, the PRC government expressed its support for the newly proposed quota and urged other countries to implement it as soon as possible. As formal agreement was reached in December of the same year during the 14th General Review, the only step left for members was to provide additional funding to be added to the agreed quota subscription. China made its contribution in 2012, leaving the United States as the last major donor to implement quota reform. However, the initially optimistic expectations did not last long, as the US Congress did not include IMF reform in its annual budget bill until 2015.

China did not conceal its disappointment in the lack of progress in IMF quota reform. When the IMF subscription was once again not included in the US 2015 fiscal year budget, Chinese Ministry of Foreign Affairs Spokesperson Hong Lei remarked that China is again "deeply disappointed" in the US Congress' failure and questioned the legitimacy of the IMF ((Xinhua News Agency 2014). In multiple editorials and interviews in the Global Times and Xinhua News, the two state-run news agencies that often deliver the PRC government's opinion, China continued to publicly condemn both the United States and the IMF for their unwillingness and inability to represent China's changing status and influence in the world.

The cycle of expectation followed by frustration also occurred in the latter half of the decade as well. When US legislators finally passed the IMF quota and governance reform bill in 2015, China welcomed the change and remarked that future IMF reforms should be conducted more swiftly to take the evolving world economic landscape into account (Xinhua News Agency 2016). Such hope for timely adjustment was once again short-lived, as the 2019 IMF regular quota review decided not to adjust the quota for another five years. After the decision to withhold the reform was announced, Yi Gang, the Governor of PBC, remarked that China was once again deeply disappointed by the stagnation and would continue to push for structural reform that "reflects members' relative positions 
in the global economy (Xinhua News Agency 2019)."

One thing to note here is that it was not only China who has been discontent with the lack of progress in IMF quota reform. In 2012, during the fourth BRICS Summit in New Delhi, the group released a statement urging the World Bank and the IMF to review their quota systems to ensure the interests of EMDCs (Gangopadhyay and Kala 2012). BRICS also called for the reform of governance structure within the World Bank and the IMF so that the heads of these multilateral institutions would be chosen through transparent and fair procedures (Li 2019).

In sum, despite the growth of many developing countries, the BWIs were slow to adjust to the dynamics of global economic development. Most significantly, rapidly developing countries were not given proper representation in these institutions. The institutional rigidity (rules and procedures governing change that are too rigid to cope with dynamic changes in the global economy and thus hinder institutional reform) of the IMF and World Bank has created a permissive environment for China's proposal to establish another international institution.

As discussed above, this institutional rigidity is further complicated by the US domestic political actors, especially the Congress, involved in IMF decision-making, to which we now turn.

\section{US DOMESTIC POLITICS}

One of the most consequential incidents that demonstrated the US Congress's enormous influence over the BWIs was the Fund's initiative to reform capital management among its members. The frequent interruptions and engagements of the US Congress that impinge on the US government's management of international economic institutions have far-reaching consequences: US domestic political power struggles between the US administration and Congress have important implications for the international economic order.

The Smithsonian Accord of 1971 effectively ended the fixed exchange rate system pegged to US dollars. The IMF, whose initial mandate had been to monitor and oversee states' devaluation and currency manipulation, had to undergo major changes in its purpose and function and began to assume a role of "lender of last resort." These changes inevitably led the Fund to surveillance of members' capital flows and the decision to systematically incorporate capital management into its core mandates (Truman 2006, 84-85).

The initial tone of the revised Articles of Agreement explicitly encouraged liberalization of international capital movement. The preamble to Article IV of the 1978 Articles of Agreement states: "the essential purpose of the international monetary system is to provide a framework that facilitates the exchange of goods, 
services, and capital among countries." Despite the organization's tacit trend toward capital liberalization, the Fund was not given the authority to dictate members' capital regulation policies, and capital controls were left to their own discretion.

The proposal to amend the Articles of Agreement to incorporate capital flow liberalization appeared in 1993 when then Managing Director Michel Camdessus brought the agenda to the Executive Board meeting (Abdelal 2007, 12-13). The newly proposed reform had two key elements. First, the IMF's purpose would include capital liberalization, and it would be codified in Article I. Second, the IMF would hold jurisdiction over capital movement among members, prohibiting them from engaging in any international capital transaction without its approval (Truman 2006, 188-197). The Secretaries of Treasury under President Bill Clinton, Robert Rubin, and Lawrence Summers, who had long been supporting the abolishment of international capital control, backed Camdessus's proposal, demonstrating the Clinton administration's strong commitment to capital movement liberalization (Stone 2011, 73-74).

However, the proposal was met by heavy resistance from the US Congress, especially from Democrats who belonged to the same party as President Clinton. In spring of 1998, House Minority Leader Richard Gephardt and several of his colleagues wrote an assertive letter to Secretary Rubin, threatening to withhold support for IMF funding if the Fund continued to seek to liberalize capital movement (Truman 2006, 191). The US Treasury Department immediately withdrew its support for the reform, and the proposal never came to pass.

This example of the IMF's attempt to liberalize and gain jurisdiction over capital movement clearly illustrates that it is the US Congress, not the President, that has the larger say in major policy change in BWIs. Given that the opposition did not come from the Republican opposition party but from the President's own party and that the administration could not pursue its agenda on IMF owing to a lack of legislator support, it is clear that US domestic political concerns lie at the heart of BWIs decision-making process.

As demonstrated by the previous case, the BWIs have been heavily intertwined with US domestic political interests, especially of the legislative branch, ever since their inception. Most pertinent to this study, US jurisdiction over IMF quota decision-making is bestowed on the US Congress. US Code 286c states:

Unless Congress by 1

aw authorizes such action, neither the President nor any person or agency shall on behalf of the United States (a) request or consent to any change in the quota of the United States under article III, section 2(a), of the Articles of Agreement of the Fund. 
The language of the code makes it clear that any change to the US quota in the IMF must obtain congressional support (Nelson and Weiss 2015, 11). That is, the administration alone cannot consent to a US quota change at the IMF nor implement an amendment to the IMF Articles of Agreement unless Congress first allows the changes to take place.

The involvement of the legislative branch in IMF quota reform is not surprising, given the fact that legislative bodies in democratic polities usually hold the "power of the purse" to allocate national budget and approve spending proposed by the executive. However, with the predominant position of the US in the IMF, the US Congress has held considerable leverage in the process of quota change (Broz and Hawes 2006, 371-373). While the IMF itself prefers quota increases, and US administrations often endorse them, the legislative affirmation entailed in the process, especially in the US, "has complicated the life of the Fund since the beginning (Pauly 1998, 113)." Woods summarizes the role of the US Congress in the BWIs as follows:

Each time an increase in IMF quotas or a replenishment of the (World) Bank's IDA has been negotiated, the Congress has used the opportunity to threaten to reduce or withhold the funds, being yet more prepared than even the executive agencies-Treasury and State Departments-to set down special preconditions for U.S. contributions. As a result, other shareholders and officials within the institutions have grown used to placating not just the powerful Departments of State and Treasury, but also the feisty U.S. Congress. The overall result seems to have enhanced the capacity of the United States unilaterally to determine aspects of policy and structure within both the IMF and the World Bank (Ngaire 2003).

Such congressional influence was apparent during the 14th General Review conducted during the Obama presidency. During the G20 Seoul Summit in 2010, both the Finance Ministers and Governors meeting and Summit meeting reached an agreement to 1) increase the base quota by $100 \%, 2$ ) transfer $6 \%$ of quota to emerging market countries, and 3) reform the IMF Executive Board selection process (Ministry of Foreign Affairs, Republic of Korea). However, following the US midterm elections in 2010, the Republicans took hold of the lower House of Representatives, which significantly reduced Obama's policy momentum.

After agreement was reached in 2010, President Obama and the US Department of the Treasury repeatedly urged Congress to pass the IMF reform bills, arguing that US interests would not be negatively impacted by the process. Two reasons were laid out by the Obama administration. First, even after the quota increase, 
the United States would maintain over $16.5 \%$ voting power, thus remaining the most powerful veto player in the organization. Second, the extra resources to be devoted to the newly formed quota would be derived from the already invested New Arrangement to Borrow (NAB) fund it had invested in the IMF prior to the reform.

However, House Republicans expressed concern about the contents of the 2010 reform, especially that of the NAB. The NAB is a set of credit arrangements between the IMF and member countries, used in circumstances in which the IMF uses when the expected need of resources surpass that of the available quota. It is understood as a "second line of defense" in a financial crisis, as the IMF's primary responsibilities involve lending out from its quota and NAB as a supplementary source of funding. Unlike quota, however, that directly translates to voting power within the organization, NAB does not affect a country's voting power.

The Republicans rather argued for maintenance and an even greater role for $\mathrm{NAB}$, as the 2010 reform intended to roll back the NAB that had already been invested in the quota. Kay Granger, Chairwoman of the House Foreign Operations Subcommittee, stated that NAB requires far stricter conditionalities and prior actions by potential recipients before they can receive funding, thus better serving the goals of the American people (Cornwell 2011). The Republicans also questioned the potential usage of quota that would allow Ukraine to borrow more money from the Fund based on its increased quota subscription (Vinik 2014). Granger succinctly summarized the overall concern of the US Congress with quota reforms, when she stated that: "the IMF is controversial within the Congress (Granger 2013)." This controversy involves the purpose and use of IMF funds in conducting US foreign policies, and the Republicans worried that IMF reform packages would reduce the influence of the United States over the IMF, while handing more power to China and other rising powers (Trindle 2014).

The passage of the 2010 reform was not a priority for the Obama administration either. Although the reform was passed in 2010, the administration did not request the financial resources it needed to support the reform until the 2014 fiscal year budget. Still, the three years of continued appeals to pass the reform and consecutive failures to do so reflect the power of the US Congress over the international institution.

The congressional power to effectively block any major changes to IMF is further complicated by the US domestic legislator-constituent relationship. Broz and Hawes argue that US policy toward the IMF is intrinsically related to the interests of legislators' primary constituents. Through empirical analysis, they find that legislatures are responsive to appeals made by banks that supply 
legislators with campaign funds as well as to the interests of other non-governmental groups whose benefit or cost is highly at stake by the IMF's bailout program (Broz and Hawes 2006, 391).

Thus far, we have demonstrated that the US Congress has a considerable command over any changes in the BWIs and has served as the major roadblock to IMF reforms. This is made possible due to domestic legislation that gives the final say to the Congress regarding matters of BWIs, and Democrats and Republicans alike have opposed the Executive's action throughout history. As a consequence, China faced increasing frustration, and we point out that this provided incentives to China and other states to seek an alternative.

\section{CONCLUSION}

Existing scholarship has analyzed the establishment of the AIIB based on speculation about China's "true" intentions. The "revisionist" camp has argued that the AIIB is an attempt to overthrow the US-led BWIs and ultimately revise the liberal economic order. On the other hand, the "status quo" side has defended the AIIB by pointing out the complementary roles it would play with the BWIs in the region. While these works have certainly contributed to the academic discussion of China's rise, the plausibility of either the "revisionist" or "status quo" position depends on the actual intentions of the Chinese government, which are hard to verify empirically. By contrast, we sidestep the debate and focus on the underlying institutional and political factors of the BWIs that pushed China to seek an alternative.

We establish the institutional rigidity of BWIs, especially that of quota reform, as the primary condition that prompted China to create the AIIB. Although the quota share is supposed to be restructured in regular intervals based on the GDP shares of BWIs member countries, it has rarely occurred, owing to procedural complications and uneven influence of certain members, especially the US. This has led to a growing discrepancy between China's actual GDP share in the world economy and its representation in the BWIs since the early 2000s. Further, the past two decades have seen China cycle between expectations of increased quota share, followed by frustration with reform failures. The Chinese government has not been shy about its frustrations, but its repeated expressions of dissatisfaction have largely been ignored within the BWIs.

The institutional rigidity of the BWIs is further complicated by the salience of US domestic politics in organizational decision-making. Since the very 
beginning, the US Congress has dictated the US government's involvement in the BWIs. With Congress retaining the constitutional power of budget appropriation, the coalition of influential legislators has effectively blocked any major BWIs reform proposals, despite the support of the US president. As members of Congress are responsive to the appeals of their organized constituents such as banks and asset management corporations, this conflict of interests between the executive and legislative bodies often resulted in the failure of BWIs reform, further discouraging China and other emerging economies from counting on the BWIs alone.

Despite these shortcomings, the BWIs' influence on global economic cooperation over the last half-century cannot be overstated. They achieved remarkable success during the most recent global economic crisis in 2008 by efficiently employing their resources and expertise. Without post-crisis management and policy guidelines from the BWIs, such a quick recovery of the global economy would not have been possible.

However, there is an emerging rivalry in the global economy between the United States and China, and this is reflected in institutional rivalry as well. Rather than relying solely on the extant BWIs and ADB, China and other emerging economies created the AIIB and NDB, where their growing economic power can be adequately represented. This rivalry is also manifested in realms of trade, where many see an emerging institutional competition between the Japan-led Trans-Pacific Partnership (TPP; originally led by the United States) and the ASEAN-led Regional Comprehensive Economic Partnership (RCEP) that China is a member.

What will be critical in the near future is the course of action taken by other countries with sufficient economic power such as major European economies and other middle powers, including Japan and South Korea. Early signs indicate a transition of momentum in favor of China, as reflected by European countries such as Britain, France, and Germany joining the AIIB. The outlook for the emerging rivalry is especially worrisome, given the growing rhetoric of US isolationism. Without the United States' active participation, the BWIs that have provided the global public goods of economic and financial stability will increasingly become ineffective, inducing more states to seek alternatives. 


\section{REFERENCES}

Abdelal, Rawi. 2007. Capital Rules: The Construction of Global Finance. Cambridge, MA: Harvard University Press.

Asian Development Bank and Asian Development Bank Institute. 2009. Infrastructure for a Seamless Asia. Tokyo: Asian Development Institute.

Asian Infrastructure Investment Bank. (n.d.). "Articles of Agreement." Asian Infrastructure Investment Bank. Accessed at https://www.aiib.org/ en/about-aiib/basic-documents/articles-of-agreement/index.html (searched date: February 11, 2020).

Bénassy-Quéré, Agnès and Sophie Béreau. 2011. "Rebalancing IMF Quotas.” The World Economy 34(2), 223-247.

Broz, J. Lawrence and Michael Brewster Hawes. 2006. "Congressional Politics of Financing the International Monetary Fund." International Organization 60(2), 367-399.

Chen, Ian Tsung-yen. 2019. "China's status deficit and the debut of the Asian Infrastructure Investment Bank." The Pacific Review 59(3), 1-31.

Chow, Daniel. C. K. 2016. "Why China Established the Asia Infrastructure Investment Bank," Vanderbilt Journal of Transnational Law 49(5), 1255-1298.

Cornwell, Susan. 2011. "Republicans Oppose U.S. Funds for IMF/Europe Bailout.” Reuters (December 9). Accessed at https://www.reuters.com/ article/us-eurozone-imf-usa/republicans-oppose-u-s-funds-for-imf-europebailout-idUSTRE7B72FV20111208.

Fioretos, Orfeo. 2011. "Historical Institutionalism in International Relations." International Organization 65(2), 367-399.

Gangopadhyay, Abhrajit and Anant Vijay Kala. "Brics Wants World Bank, IMF Reforms." Wall Street Journal

Granger, Kay. 2013. "Lew faces skeptical Congress with IMF funding request." U.S. Congresswoman Kay Granger 12th District of Texas Web-page (April 24). Accessed at https://kaygranger.house.gov/lew-faces-skeptical-congressimf-funding-request (searched date: 27 December 2019).

$\mathrm{Gu}$, Bin. 2017. "Chinese Multilateralism in the AIIB." Journal of International Economic Law 20, 137-158.

. 2018. The Law and Governance of the Asian Infrastructure Investment Bank. Alphen aan den Rijn: Wolters Kluwer.

The G20 Research Group. 2010. "Meeting of Finance Ministers and Central Bank Governors." The G20 Information Centre (June 5). Accessed at http:// www.g20.utoronto.ca/2010/g20finance100605.html (searched date: December 
10, 2019).

Hall, Peter A. and Rosemary C.R. Taylor. 1996. "Political Science and the Three New Institutionalisms.” Political Studies 44(5), 936-957.

Hameiri, Shahar and Lee Jones. 2018. "China challenges global governance? Chinese international development finance and the AIIB.” International Affairs 94(3), 573-593.

He, Kai and Huiyun Feng. 2019. "Leadership Transition and Global Governance: Role Conception, Institutional Balancing, and the AIIB." The Chinese Journal of International Politics 12(2), 153-178.

Heep, Sandra. 2014. China in Global Finance: Domestic Financial Repression and International Financial Power. Heidelberg: Springer.

Higgins, Andrew and David E. Sanger. 2015. "3 European Powers Say They Will Join China-Led Bank.” New York Times (March 17). Accessed at https:/ www.nytimes.com/2015/03/18/business/france-germany-and-italy-joinasian-infrastructure-investment-bank.html (searched date: 10 December 2019).

International Monetary Fund. 2015. “Quota Formula - Data Update.” International Monetary Fund Staff Report (June 19). Accessed at https://www.imf. org/en/Publications/Policy-Papers/Issues/2016/12/31/Quota-FormulaData-Update-PP4967 (search date: March 13, 2021)

International Monetary Fund. 2019. “IMF Quotas.” International Monetary Fund (March 8). Accessed at https://www.imf.org/en/About/Factsheets/ Sheets/2016/07/14/12/21/IMF-Quotas (searched date: December 5, 2019).

Jensen, Nathan M. 2004. "Crisis, Conditions, and Capital: The Effect of International Monetary Fund Agreements on Foreign Direct Investment Inflows.” Journal of Conflict Resolution 48(2), 194-210.

Johns, Leslie. 2014. "Depth versus rigidity in the design of international trade agreements. "Journal of Theoretical Politics 26(3), 468-495.

Kaya, Ayse. 2015. Power and Global Economic Institutions. Cambridge: Cambridge University Press.

Kevin P. Gallagher et al. 2016. "Fueling Growth and Financing Risk: The benefits and risks of China's development finance in the global energy sector." Boston University Global Economic Governance Initiative, Working Paper 002.

Koremenos, Barbara. 2005. "Contracting around International Uncertainty." American Political Science Review 99(5), 549-565.

Krasner, Stephen D. 1984. "Approaches to the State: Alternative Conceptions and Historical Dynamics.” Comparative Politics 16(2), 223-246.

Li, Li. 2019. "BRICS: A Limited Role in Transforming the World." Strategic 
Analysis 43(6), 499-508.

Liao, Rebecca. 2015. "Out of the Bretton Woods: How the AIIB is Different."

Foreign Affairs (July 27). Accessed at https://www.foreignaffairs.com/ articles/asia/2015-07-27/out-bretton-woods (searched date: November 28, 2019).

Lipscy, Phillip Y. 2015. "Explaining Institutional Change: Policy Areas, Outside Options, and the Bretton Woods Institutions." American Journal of Political Science 59(2), 341-356.

Lustick, Ian S. 2011. "Institutional Rigidity and Evolutionary Theory: Trapped on a Local Maximum.” Journal of Theoretical and Mathematical History 2(2), 3-20.

March, James G. and Johan P. Olsen. 1984. "The New Institutionalism: Organizational Factors in Political Life.” American Political Science Review 78(3), 734-749.

Ministry of Foreign Affairs. (n.d.). "Overview: International Organization." Ministry of Foreign Affairs, Republic of Korea. Accessed at http://www. mofa.go.kr/eng/wpge/m_5470/contents.do (searched date: November 28, 2019).

Nelson, Rebecca M. and Martin A. Weiss. 2015. "IMF Reforms: Issues for Congress." Congressional Research Service R42844.

North, Douglass C. 1990. Institutions, Institutional Change, and Economic Performance. Cambridge: Cambridge University Press.

Pauly, Louis W. 1998. Who Elected the Bankers? Surveillance and Control in the World Economy. Ithaca, NY: Cornell University Press.

Przeworski, Adam and James Raymond Vreeland. 2000. "The Effect of IMF Programs on Economic Growth." Journal of Development Economics 62(2), 385-421.

Ren, Xiao. 2016. "China as an institution-builder: the case of the AIIB." The Pacific Review 29(3), 435-442.

Rosendorff, B. Peter. 2005. "Stability and Rigidity: Politics and Design of the WTO's Dispute Settlement Procedure.” American Political Science Review 99(3), 389-400.Ruiz-Nunez, Fernanda and Zichao Wei. 2015. "Infrastructure Investment Demands in Emerging Markets and Developing Economies" World Bank Group, Policy Research Working Paper No. WPS7414 (September). Accessed at http://documents.worldbank. org/curated/en/141021468190774181/pdf/WPS7414.pdf (searched date: November 25, 2019).

Steinmo, Sven. 2001. "New Institutionalism.” In Paul Berry Clarke, ed., Encyclopedia of Democratic Thought, New York: Routledge, 570-574. 
Stephen, Matthew D. and David Skidmore. 2019. "The AIIB in the Liberal International Order.” The Chinese Journal of International Politics 12(1), 61-91.

Stone, Randall W. 2011. Controlling Institutions: International Organizations and the Global Economy. Cambridge: Cambridge University Press.

Terada, Takashi. 2016. "Japan and Geo-Economic Regionalism in Asia: The Rise of TPP and AIIB." EAI Issue Briefing (February 03). Accessed at https:// www.researchgate.net/publication/307466185 (searched date: November 20, 2019).

Thacker, Strom C. 1999. "The high politics of IMF lending.” World Politics 52, 38-75.

Trindle, Jamila. 2014. "Lagarde Pushes U.S. Lawmakers to Pass IMF Reforms." Foreign Policy (October 29). Accessed at https://foreignpolicy.com/2014/ 10/29/lagarde-pushes-u-s-lawmakers-to-pass-imf-reforms/ (searched date: November 20, 2019).

Thelen, Kathleen. 2009. "Institutional Change in Advanced Political Economies." British Journal of Industrial Relations 47(3), 471-498.

Truman, Edwin M. 2006. Reforming the IMF for the 21st Century. Washington D.C.: Peterson Institute for International Economics.

Vinik, Danny. 2014. "Republicans Are Playing Politics While Ukraine Faces Default." The New Republic (March 7). Accessed at https://newrepublic. com/article/116894/republicans-are-blocking-imf-reforms-help-ukraine (searched date: November 20, 2019).

Voeten, Erik. 2019. "Making Sense of the Design of International Institutions." Annual Review of Political Science 22, 147-163.

Vreeland, James Raymond. 2007. The International Monetary Fund: Politics of conditional lending. New York: Routledge.

Wang, Hongying. 2015. "The Asian Infrastructure Investment Bank: A New Bretton Woods Moment? A Total Chinese Triumph?” CIGI Policy Brief No. 59. Accessed at https://www.cigionline.org/publications/asian-infrastructuredevelopment-bank-new-bretton-woods-moment-total-chinese-triumph (searched date: November 17, 2019).

Weiss, Martin A. 2017. "Asian Infrastructure Investment Bank (AIIB)." Congressional Research Service, R44754.

Woods, Ngaire. 2003. "The United States and the International Financial Institutions: Power and Influence within the World Bank and the IMF. In Rosemary Foot.” In S. Neil MacFarlane and Michael Mastanduno eds., U.S. Hegemony and International Organizations: the United States and Multilateral Institutions, Oxford: Oxford University Press, 92-115. 
Wu, Chien-Huei. 2018. "Global Economic Governance in the Wake of Asian Infrastructure Investment Bank: Is China Remaking Bretton Woods?” Journal of World Investment \& Trade 19, 542-569.

Wyplosz, Charles. 1999. "International Financial Instability." In Inge Kaul, Isabelle Grunburg and Marc Stern eds., Global Public Goods: International Cooperation in the 21st Century, Oxford: Oxford University Press, 152189.

Xinhua News Agency. 2009. "China, Russian sign five-point joint statement." China Daily (June 18). . 2014. "China disappointed about US failure to approve IMF reform plan" Global Times (December 12).

. 2016. "Time for global governance reform to catch up." Global Times (September 02).

. 2019. "China's central bank governor "disappointed" with failure of IMF quota increase." Global Times (October 20).

[Received Oct 30, 2020; Revised Mar 22, 2021; Accepted Apr 2, 2021] 